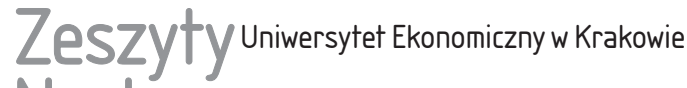 Naukowe
}

Towaroznawstwo

\section{Andrzej Gajewski}

Katedra Metrologii i Analizy Instrumentalnej

Uniwersytet Ekonomiczny w Krakowie

\section{Integracja HCD i TRIZ w projektowaniu i ocenie wyrobów}

\section{Streszczenie}

HCD to dogłębne poznanie i zrozumienie potencjalnych klientów, ich określonych czynności, preferencji, emocji, motywacji, problemów i środowiska, w jakim przebywają. TRIZ zorientowane jest na rozwiązywanie problemów technicznych ze szczególnym uwzględnieniem innowacji technologicznych. TRIZ i HCD to zupełnie inne filozofie projektowania, wytwarzania i oceny wyrobów. Wydaje się jednak, że spojrzenie na wyrób z punktu widzenia metodologii zarówno TRIZ, jak i HCD jest szansą na właściwy, zgodny z oczekiwaniem konsumentów rozwój towarów, szczególnie towarów konsumpcyjnych. W artykule przedstawiono przykładowe obszary, w których główny nacisk położony jest na użyteczność danego wyrobu (tu zastosowanie znajdują metody TRIZ), oraz obszary, w których większe znaczenie mają metody zastosowane w HCD.

Słowa kluczowe: HCD, TRIZ, rozwój wyrobów, ocena wyrobów, struktura użycia, użyteczności i znaczenia.

\section{Wprowadzenie}

Wydawać się może, że potrzeby i oczekiwania klienta są w zgodzie z doskonałością techniczną wyrobów. Najczęściej tak bywa, nie jest to jednak regułą, co zostanie pokazane w dalszej części artykułu. Celem tej publikacji jest zaprezentowanie skuteczności integracji HCD i TRIZ w projektowaniu i ocenie wyrobów.

Human-centered design (HCD) to dogłębne poznanie i zrozumienie potencjalnych klientów, ich określonych czynności, preferencji, emocji, motywacji, problemów i środowiska, w jakim przebywają. HCD to zasady projektowania 
ukierunkowanego na użytkownika i kładącego nacisk na dogłębne zrozumienie potrzeb konsumenta.

Teoria rozwiązywania innowacyjnych zadań (TRIZ) jest metodą rozwiązywania problemów w oparciu o logikę i konkretne dane empiryczne, jest metodyką kreatywnego rozwiązywania problemów. TRIZ daje możliwość rozwiązywania problemów za pomocą stałego, powtarzalnego algorytmu. Łamie stare formy wynikające z intuicji, edukacji, doświadczenia, pozwala na pokonanie, a w każdym razie ograniczenie, wektora inercji. Eliminuje czasochłonne rozwiązywanie problemów metodą prób i błędów. Zwiększa liczbę trafnych rozwiązań, oszczędza czas i pieniądze oraz ogranicza ryzyko [Gajewski 2006 i 2007].

HCD i TRIZ to zupełnie inne filozofie projektowania, wytwarzania i oceny wyrobów. Wydaje się jednak, że spojrzenie na wyrób z punktu widzenia metodologii zarówno HCD, jak i TRIZ jest szansą na właściwy, zgodny z oczekiwaniem konsumentów rozwój towarów, szczególnie konsumpcyjnych. W artykule przedstawione zostaną obszary, w których główny nacisk położony jest na użyteczność danego wyrobu (tu zastosowanie znajdują metody TRIZ), oraz obszary, w których większe znaczenie mają metody zastosowane w HCD. Właściwe zrozumienie istoty HCD i TRIZ w rozwoju towarów umożliwia przedstawiona w artykule struktura użycia, użyteczności i znaczenia (use, usability, meaning). Zaprezentowano też przykłady obszarów, w których mogły bądź mogą być razem zastosowane obie metody.

\section{Istota HCD}

Poznanie skomplikowanych i często trudnych do zrozumienia upodobań, preferencji i motywacji potencjalnych klientów związanych ze specyficznym środowiskiem, w jakim przebywają, zrozumienie owych motywacji, a także sposobów rozwiązywania problemów i pokonywania przeciwności pojawiających się w ich życiu to podstawowe zadania HCD. Celem jest poznanie indywidualnych potrzeb potencjalnych klientów i ich przywiązania do określonych produktów. Kiedy już producent ma pełny obraz konsumentów, może zacząć opracowywać strategię skierowaną do określonej grupy użytkowników, tak aby produkt spełniał ich oczekiwania.

Główną metodą badań HCD jest, jak to określają A.V. Pelt i J. Hey [2006] oraz D.L. Mann [2006], etnografia. Jest to antropologiczna technika używana do obserwacji ludzi w ich naturalnym środowisku. Może to być np. obserwowanie ich codziennego życia lub stanie się aktywnym uczestnikiem ich codziennych czynności. Chodzi o to, by zacząć patrzeć na świat dokładnie tak jak oni. Przeprowadzenie obserwacji konkretnej sytuacji jest bardzo ważne, gdyż konsumenci 
często nieświadomie reagują na bodźce z zewnątrz. Przykładem może być sytuacja, w której tym samym napojem napełniono zwykłą butelkę i butelkę ekstrawagancką. Napój z ekstrawaganckiej butelki smakuje lepiej. Ponadto trzeba mieć świadomość, że często to, co rzeczywiście ludzie myślą lub czują, może bardzo się różnić od tego, co mówią, że czują, w zależności od kontekstu i sytuacji, w jakiej się znajdują. HCD jest metodologią podkreślającą znaczenie głębokiego zrozumienia konsumentów. Jest to swego rodzaju metoda prób i błędów. Jest ona przeciwieństwem metodologii TRIZ, której istotą jest analiza prowadząca do rozwiązania problemu. Może właśnie dlatego wielu naukowców próbuje łączyć te dwie metodologie. Coraz częstsze stosowanie TRIZ do rozwoju produktów konsumenckich i większy asortyment produktów sprawiają, że integracja tych dwóch metod staje się coraz ważniejsza.

\section{Metodologia TRIZ}

Nazwa TRIZ pochodzi z języka rosyjskiego (teorâ rešencâ izobretatel'skih zadač) ${ }^{1}$. Twórcą tej metody jest H.S. Altszuller. TRIZ to teoria wynalazczości pozwalająca na maksymalną sprawność i metodyczne rozwiązywanie problemów. Zasadniczym postulatem TRIZ jest twierdzenie: ,skoro techniczne systemy rozwijają się według określonych prawidłowości, to te prawidłowości można odkryć i wykorzystać do stworzenia algorytmów rozwiązywania zadań wynalazczych" [Gajewski 2007]. W swej pierwotnej postaci TRIZ był opracowany do rozwiązywania problemów technicznych, wynalazczych. Obecnie jest stosowany do rozwiązywania problemów organizacyjnych, edukacyjnych, społecznych, a także biznesowych [Gajewski 2006 i 2007]. Znaczenie TRIZ daje się zauważyć głównie w ostatnich dwóch dekadach. Przyczynił się m.in. do rozwoju produktów takich międzynarodowych korporacji, jak Samsung, Motorola, Xerox i in. [Pelt i Hey 2006]. Wielu menedżerów, np. w Motoroli, zapowiada, że TRIZ stanie się tak ważny w zarządzaniu i analizie innowacji jak six sigma w zapewnieniu jakości, zaznaczają oni ponadto, że metody te znakomicie się uzupełniają [Barney i McCarty 2005]. Rozwijający się trend stosowania TRIZ w procesie projektowania dóbr konsumpcyjnych oraz jego integracji z metodologią HCD podejmują np. J. Hipple [2006], R. Jana [2006] i D.L. Mann [2006]. Autorzy ci wyrażają przekonanie, że stosowanie obu rozwiązań może przynieść wiele korzyści. Proponują zintegrować „głos konsumenta” (voice of consument) i TRIZ głównie w fazie definiowania problemu. Przykładem może być D.L. Mann [2006], próbujący integrować TRIZ z metodą quality functional deployment (QFD), znaną jako

${ }^{1}$ W literaturze światowej najczęściej stosowana jest oryginalna pisownia TRIZ, w literaturze anglosaskiej spotyka się jednak nazwę theory of inventive problem solving (TIPS). 
house of quality. Godne uwagi są również prace J. Hipple’a [2006] oraz T. Runhui [2002]. Warto jednak zaznaczyć, że każda z tych metod wymaga wyczerpującego poznania i zrozumienia całego obszaru zagadnień wiążących się z produktem.

TRIZ nie został pomyślany jako narzędzie służące do dogłębnego zrozumienia potrzeb konsumenta. Skupia się on głównie na innowacyjności urządzeń technicznych, wychodzi naprzeciw klientom szukającym czegoś nowego. Jest to powszechna tendencja wynikająca z postępu technicznego i ludzkich oczekiwań. Przekładanie indywidualnych potrzeb na język funkcji TRIZ jest kluczowym, chociaż skomplikowanym zadaniem. Wiadomo bowiem, że doskonały rozwój produktu wymaga dogłębnego zrozumienia takich czynników, jak ludzkie potrzeby, wyznawane wartości, znaczenie wyrobów i niewypowiedziane (uśpione) potrzeby. Taką uśpioną potrzebą może być np. potrzeba bycia oryginalnym, zabieganym, bardzo zajętym.

\section{Potrzeby konsumenta a doskonałość techniczna wyrobu}

Warto zacząć od zaprezentowania studiów przypadków pokazujących jak kluczowe jest zrozumienie potrzeb użytkownika. Pierwszy przykład dotyczy NTT DoCoMo, największego operatora telefonii komórkowej w Japonii. Nazwa DoCoMo jest skrótem od słów do communications over the mobile network, jednocześnie w języku japońskim doko-mo oznacza „wszędzie”. Firma dostarcza usług mobilnych (telefonia, wideotelefonia, internet, mail oraz SMS). Menedżerowie DoCoMo w ostatnich latach XX w. zapowiedzieli, że ze swoim wyrobem wyruszają na podbój świata. Sztandarowa funkcja ich sieci - mobilny dostęp do internetu (ponad 15 lat temu!) - była poza konkurencją i zyskała powszechne uznanie w Japonii. Menedżerowie niedoszłego zdobywcy świata okazali się jednak głusi na potrzeby klientów spoza Japonii. Okazało się bowiem, że długie i skomplikowane menu, które przypadło do gustu Japończykom, zupełnie nie spodobało się obcokrajowcom, którzy wolą bardziej intuicyjne interfejsy. Czerpiąc być może z doświadczeń DoCoMo, firma Fujitsu, obecnie czołowy producent sprzętu IT, postanowiła produkować wyroby z uwzględnieniem zasad HCD. Głównym celem było łatwe użycie produkowanych urządzeń i systemów, bezproblemowe z punktu widzenia użytkownika. W swoich projektach firma Fujitsu wykorzystała ponadto idę ergonomii przez promowanie tworzenia systemów informatycznych uwzględniających fizyczne i poznawcze właściwości człowieka. Przyjęte zasady produkcji i perfekcja wyrobów sprawiają, że ta japońska korporacja produkująca komputery (i superkomputery), telefony komórkowe, serwery i wiele innych produktów IT zdobywa rynki światowe. Firma zatrudnia obecnie w 70 krajach ponad 175 tys. pracowników. Od 1999 r. produkuje w Europie sprzęt pod nazwą Fujitsu Siemens 
Computers, a w 2008 r. przejęła wszystkie udziały Siemens (http://fujitsu.com, 30.11.2013).

Kolejny przypadek jest jeszcze bardziej przekonujący, a dotyczy również Japonii. Na początku 1975 r. firma Sony wypuściła na rynek pierwszy amatorski format kaset wideo do magnetowidów pozwalający użytkownikom na nagrywanie programów z telewizji i kamer (system Betamax). Był to system o dobrej jakości zapisu obrazu (rozdzielczość pozioma 270 linii) i dźwięku. Niecałe dwa lata później (koniec 1976 r.) firma JVC zaprezentowała konkurencyjny produkt znany jako VHS, o gorszych parametrach zapisu obrazu (rozdzielczość pozioma 240 linii) i gorszej jakość dźwięku. Zaletami VHS były tylko dłuższy czas nagrań (ponad 1 godz.) i mniejsze gabaryty kaset. Firma Sony konkurowała przez lata z gorszym technologicznie VHS. W latach 80 . VHS wygrał walkę o prymat na rynku z bardziej zaawansowanymi technologicznie konkurencyjnymi formatami Betamax (Sony) oraz Video 2000 (Philips). O zwycięstwie zadecydowała niska cena VHS oraz brak promocji i błędy w polityce firmy Sony. Rynek niespodziewanie zwrócił się w stronę VHS, a klęska Sony była upokarzająca - pod koniec lat 80. firma została zmuszona do zakupy licencji VHS i zaczęła sprzedawać swoje własne wyroby systemu VHS, czyli systemu konkurenta.

Powstaje pytanie, jak to możliwe, że firma JVC zdołała pokonać Betamax. Wskazać można trzy główne przyczyny zaistniałej sytuacji [Pelt i Hey 2006]:

1) brak odpowiedniej promocji produktu Sony (w owym czasie zupełnie nieznanego na rynku),

2) niższe koszty VHS pod koniec lat 70. ubiegłego wieku,

3) niedocenienie przez Sony potrzeb konsumentów, którzy wybrali dłuższy czas nagrywania (przy gorszej jakości) oraz mniejsze kasety.

Sony nie zrozumiał potrzeb konsumentów, którzy wybrali dłuższy czas nagrywania oraz mniejsze kasety zamiast wyższej jakości. Gwoli sprawiedliwości należy jednak dodać, że wyższa jakość nagrań w formacie Betamax nie była wyraźnie zauważalna dla większości użytkowników. Niemniej błędy Sony były dość typowe dla producentów.

Opisane przypadki są jednymi z wielu. Wnioski, które się nasuwają, są następujące: 1) lepsze technologicznie rozwiązania nie zawsze znajdują uznanie klientów, 2) producenci tak naprawdę nie znają swoich potencjalnych klientów w stopniu pozwalającym im na dotarcie do nich ze swoimi produktami i z nowościami.

\section{Porównanie TRIZ i HCD}

W metodologii TRIZ najważniejsze są zdefiniowanie problemu i możliwie najlepsza technologia, w przypadku HCD to użytkownik i jego potrzeby mają 
największe znaczenie. W praktyce HCD głównym celem jest obserwacja potrzeb wynikających ze sprzeczności ludzkiego zachowania. Wykorzystujący TRIZ w swoich badaniach na pierwszym planie stawiają cechy fizyczne i techniczne danego problemu lub badanego przedmiotu. Oba sposoby mają cechy wspólne: badania i analiza są przeprowadzane w celu znalezienia rozwiązania danego problemu, a nie jego oceny. D.L. Mann [2006] rozwinął proces badania przez wprowadzenie czterech kroków; są to: zdefiniowanie, wybór narzędzi, wypracowanie rozwiązania oraz ocena. Tymczasem narzędzia TRIZ służą przede wszystkim do zdefiniowania problemu. $Z$ doświadczenia wynika, że często użytkownicy TRIZ definiują problem na podstawie niewystarczających informacji, np. pochodzących od zarządu, uwzględniają marketingowy punkt widzenia lub własne doświadczenie, rezygnują natomiast z rzeczywistego zbadania użytkownika. Jest to dość ryzykowne, jeśli wziąć pod uwagę przyszłość produktu na rynku.

Tabela 1. Podstawowe różnice pomiędzy TRIZ i HCD

\begin{tabular}{|l|l|}
\hline \multicolumn{1}{|c|}{ TRIZ } & \multicolumn{1}{c|}{ HCD } \\
\hline Nastawienie na funkcjonalność i technikę & Nastawienie na ludzkie potrzeby \\
\hline Maksymalizacja technicznego sukcesu & Techniki antropologiczne \\
\hline Podkreślanie twierdzeń nieopartych na faktach & Podkreślanie kontekstu \\
\hline Podejście mocno zestrukturyzowane & Podejście mało zestrukturyzowane \\
\hline Określa co i jak & Opisuje dlaczego \\
\hline
\end{tabular}

Źródło: [Pelt i Hey 2006].

Zbyt często metodolodzy HCD porzucają technologiczną innowacyjność i wykorzystują tradycyjną burzę mózgów oraz doświadczenie grupy przeprowadzającej badania.

\section{Integracja TRIZ i HCD}

Zgodnie z propozycjami wielu teoretyków i praktyków zarządzania jakością tylko integracja kilku metod badawczych może doprowadzić do prawidłowych wniosków i właściwej decyzji. Rozważania takie prowadzi np. E. Sanders [1990], która stwierdza, że zwykle poszczególne metody mają wspólny element, który dzięki uwzględnieniu zaleceń poszczególnych metod i wyników poszukiwań tymi metodami (findings) daje uzasadnione powody do podjęcia właściwej decyzji (rys. 1). 


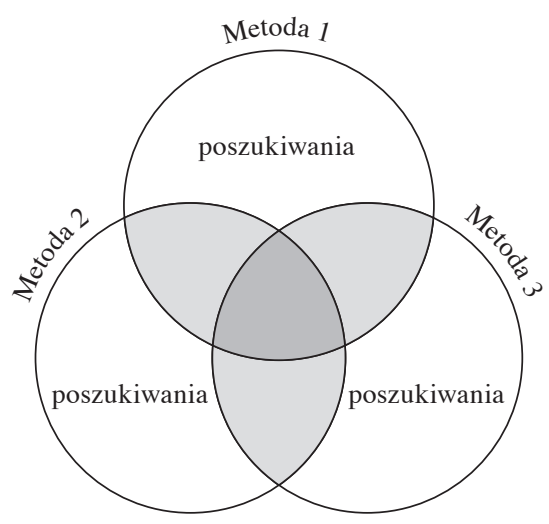

Rys. 1. Integracja kilku metod badawczych pozwalająca na określenie elementów wspólnych

Źródło: [Sanders 1990].

Podobnie wypowiadają się A.V. Pelt i J. Hey [2006]. Aby zaprezentować możliwości, jakie daje integracja TRIZ i HCD, proponują teorię, którą nazywają: użycie, użyteczność i znaczenie (rys. 2).

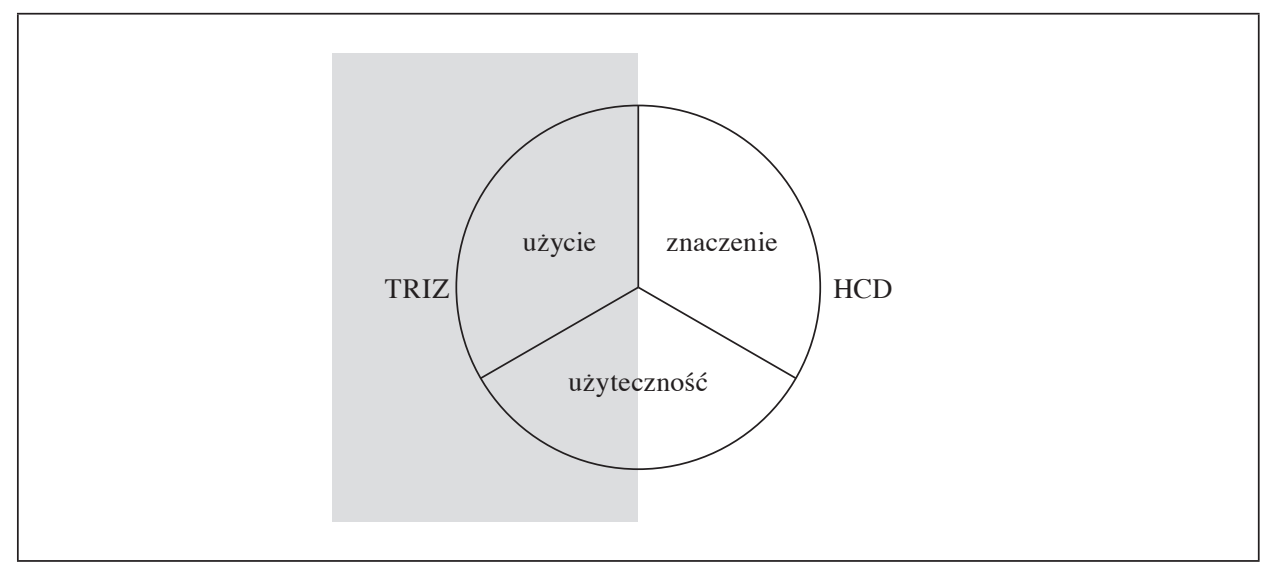

Rys. 2. Diagram przedstawiający zakresy znaczeniowe preferowane przez TRIZ i HCD Źródło: [Pelt i Hey 2006].

Użycie odnosi się do tego, co użytkownik może zrobić z danym produktem i jakie korzyści może z niego czerpać (w tym znaczeniu użycie jest w metodologii TRIZ synonimem funkcjonowania). Użyteczność odnosi się do sposobu, w jaki 
użytkownik posługuje się danym produktem, i łatwości, z jaką się nim posługuje. Jest to coś więcej niż łatwość w obsłudze - to również przeznaczenie produktu i korzyści z niego. Znaczenie jest najbardziej złożoną z tych cech. Produkt dla konsumenta jest czymś więcej niż tylko sumą funkcji, jakie pełni. Znaczenie wynika nie tylko z użycia i użyteczności danego produktu, ale również z reklamy i marki. Znaczenie produktu zależy od związku pomiędzy nabytą rzeczą a osobistym doświadczeniem i potrzebami konsumenta.

Relatywna wartość każdej z trzech cech - użycia, użyteczności i znaczenia - zależy od rodzaju produktu i jego przeznaczenia. Techniczne zasady działania silnika kosiarki do trawy są zapewne nieistotne dla konsumentów, którzy dbają tylko o to, by mieć ładnie przycięty trawnik, natomiast brzmienie silnika motoru Harleya Davidsona jest bardzo istotne dla jego użytkowników - kojarzy się z przygodą, siłą, daje poczucie wolności, dowartościowuje [Runhua 2002].

\section{Zastosowanie TRIZ i HCD}

Wydaje się, że najlepszą propozycją jest badanie konsumentów uwzględniające intensywność i typ interakcji między konsumentem i technologią. Im bardziej bezpośrednia interakcja między klientem i produktem, tym większa potrzeba zastosowania HCD w celu zrozumienia klienta i częstego uzyskiwania od niego informacji zwrotnych.

Produkty można sklasyfikować według relatywnych preferencji użycia, użyteczności oraz znaczenia wynikających z przyjęcia danego produktu. Produkty, w przypadku których użycie jest czynnikiem podstawowym, a znaczenie i użyteczność odgrywają niewielką rolę, reprezentują technologie under the hood (,to, co pod maską"), charakteryzują się niewielką bezpośrednią interakcją z użytkownikiem [Pelt i Hey 2006]. Dotyczy to np. technicznych problemów związanych z wnętrzem silnika lub mechaniką lodówki. Tego typu problemy mogą zostać skutecznie zbadane przy minimalnej wiedzy na temat użytkownika, a więc można w ich przypadku w wysokim stopniu, jeśli nie wyłącznie, polegać na metodologiach TRIZ.

Problemy związane z użytecznością wymagają wiedzy na temat użytkowników. Należy ustalić miejsce i czas, w których użytkownik natrafia na problemy, tymczasowe rozwiązania oraz dokładnie określić różnice pomiędzy oczekiwaniami konsumentów a tym, czego doświadczyli. W tym przypadku także TRIZ znajduje swoje zastosowanie, szczególnie wtedy gdy problemy użyteczności mają charakter fizyczny; np. w ergonomii trendy ewolucji technologicznej skutecznie wskazują projektantom możliwość ulepszenia rozwiązań. Prawidłowo określony system TRIZ okazuje się również skuteczny w rozwiązywaniu problemów typu 
„coś za coś” (wyborów). Przykładem może być równowaga pomiędzy elastycznością i użytecznością w wielu systemach zdalnego sterowania (większej elastyczności systemu towarzyszy większa liczba przycisków na pilocie, co sprawia, że obsługa staje się bardziej skomplikowana) [Pelt i Hey 2006].

Produkty wymagające świadomego przyjęcia oraz interakcji użytkowników (np. telefony komórkowe i ubrania) muszą często pasować do systemu znaczeń użytkownika i wymagają szerszego zastosowania metod HCD niż metod TRIZ. Ważne jest dogłębne zrozumienie postaw, przekonań, wartości oraz oczekiwań konsumenta, podobnie jak wpływu zmian w użyciu i użyteczności na te czynniki. Trzy obszary są ze sobą ściśle powiązane i wzajemnie na siebie oddziaływają. Przekazanie innowacyjnych rozwiązań technicznych marketingowi w celu określenia dla nich znaczenia rzadko prowadzi do powstania prawdziwie udanych produktów. Nawet produkty nastawione głównie na użycie mogą i powinny wykorzystywać techniki HCD.

Nie oznacza to, że metoda TRIZ nie może być skuteczna w rozwiązywaniu problemów związanych ze znaczeniem. Tak naprawdę w każdym z trzech wymiarów: w użyciu, użyteczności oraz znaczeniu TRIZ okazuje się skuteczny, określając strukturę pozwalającą na jasne zdefiniowanie relacji oraz celów końcowych. Pięć filarów TRIZ, tj. idealność, funkcjonalność/atrybuty, interfejs przestrzenny/czasowy, zasoby oraz eliminacja sprzeczności, stanowi - przynajmniej w wymiarze filozoficznym - skuteczne podejście do każdego wyrobu, a dalsze badania mogą być źródłem nowych korzyści [Sanders 1990]. Przykładowo w trakcie definiowania problemu można rozważyć następujące istotne pytania dotyczące idealności: jakie są idealne końcowe wyniki związane z każdym użyciem, użytecznością oraz znaczeniem? czy możliwe jest zaspokojenie potrzeby bez ponoszenia kosztów bądź innych strat? co powstrzymuje nas od osiągnięcia idealnego wyniku i dlaczego?

Filozofia TRIZ oparta na bezkompromisowej eliminacji sprzeczności jest również bardzo skuteczna w rozwiązywaniu problemów sprzecznych potrzeb użytkowników, niezależnie od tego, czy odnoszą się do użycia, użyteczności, czy też znaczenia (np. potrzeba wyższego poziomu adrenaliny, a z drugiej strony potrzeba bezpieczeństwa).

\section{Wnioski}

Należy podkreślić konieczność zachowania ostrożności w przypadku stosowania wyłącznie metod TRIZ w celu tworzenia produktów, gdyż TRIZ nie posiada narzędzi pozwalających na zrozumienie klientów, ci zaś mogą mieć skomplikowane i ukryte potrzeby wykraczające poza ramy prostej funkcjonalności, 
szczególnie w odniesieniu do systemów znaczeń. Metody TRIZ i HCD skutecznie się uzupełniają i jest możliwość sprawdzenia każdej z nich pod względem użycia, użyteczności oraz znaczenia. Istnieje uzasadniona potrzeba dalszych badań w celu określenia narzędzi i procesów określających wzajemne powiązania stosowanych metod. W literaturze światowej dotyczącej zarządzania jakością coraz częściej pojawiają się próby łączenia TRIZ z HCD oraz six sigma. Wydaje się, że omówiona w tym artykule koncepcja integracji TRIZ i HCD w ocenie wyrobów może być z powodzeniem uzupełniona o metodologię six sigma. Te trzy narzędzia, mające ugruntowaną pozycję w teorii i praktyce dążenia do doskonałości, znakomicie się uzupełniają, a ponadto mają wspólne cele, jakimi są poprawa jakości, uzyskanie wymiernych korzyści finansowych wynikających z redukcji kosztów wytwarzania, kosztów eksploatacyjnych oraz oszczędności czasu.

\section{Literatura}

Barney M., McCarty T. [2005], Nowa Six Sigma, Helion, Gliwice.

Gajewski A. [2006], Metoda TRIZ w towaroznawstwie, „Towaroznawcze Problemy Jakości”, nr 4(9).

Gajewski A. [2007], Metoda TRIZ w towaroznawstwie (cz. 2), „Towaroznawcze Problemy Jakości", nr 3(12).

Hipple J. [2006], The Use of TRIZ Principles in Consumer Product Design, Proceedings: Papers presented at the Altshuller Institute for TRIZ Studies Symposiums (TRIZ CONs) on TRIZ Methodology and Application, June.

Jana R. [2006], The World According to TRIZ, Business Week Online, May.

Mann D.L. [2006], Unleashing the Voice of the Product and the Voice of the Process, „TRIZ Journal”, June.

Pelt A.V., Hey J. [2006], Using TRIZ and Human-Centered Design for Consumer Product Development, Proceedings of the ETRIA TRIZ Future Conference 2006, Held in Kortrijk, Belgium, October 9-11.

Runhua T. [2002], Voice of Customers Pushed by Directed Evolution, „TRIZ Journal”, June.

Sanders E. [1990], Converging Perspectives: Product Development Research for the 1990s, http://www.maketools.com/pdfs/ConvergingPerspectives_Sanders_92.pdf (dostęp: 31.12.2010).

\section{Integrating HCD and TRIZ in the Design and Evaluation of Products}

Human-centered design (HCD) is a set of user-oriented principles focused on a thorough understanding of consumer needs. TRIZ focuses on the innovativeness of technical devices. TRIZ and HCD represent quite different "philosophies" of the design, manufacture and assessment of goods. It seems, however, that viewing a product from the perspective of both TRIZ and HCD methodologies provides an opportunity for consumer-focused 
development of products, especially consumer goods. The paper presents the cases in which emphasis is placed on product usability (TRIZ methods are applicable) as well as those areas in which HCD methods play a more significant role.

Keywords: HCD (human-centered design), TRIZ, development of products, estimation of products, structure of use, meaning and usability. 